\title{
ACTIVITIES OF AGENTS UNDER THE MCCARRAN ACT
}

\author{
Charles P. Butrler*
}

The impact of the decision in the case of United States v. South-Eastern Underwriters Association ${ }^{1}$ is now revealed indisputably as a force with continuing effects.

The McCarran Act ${ }^{2}$ alleviated the effect of such a sudden change in the legal concept of the insurance business and, because of the cooperation between the state governments and the industry, state laws have been enacted for the purpose of obviating an assumed necessity of asserting federal regulation over the business of insurance.

Some students of government and some students of insurance, with good motives, may be straining to find reasons that would justify the insertion of the Federal Government into our present concept of supervision of insurance by the states. Reasonable grounds for the enlargement of our governmental concept of supervision such as to provide an area therein for the Federal Government are not readily discernible, unless one indulges in a conviction that federal regulation added to state regulation or any substitution therefor would be a desired panacea.

There is absolutely no problem confronting the insurance business and no problem confronting the states in their supervision of that business which cannot be better solved under the present concept of governmental supervision by the states. The fact that the character of supervision by the states and interstate cooperation both can be improved, in no way denies the soundness of the concept of supervision of the insurance business by the states. Likewise, inter-cooperation in the industry and on behalf of state supervision can be improved. Again this is no denial of the soundness of the concept of supervision by the states.

If ever the Federal Government takes a much more active part in governmental supervision of the insurance business, the influence that will measure the degree of the Federal Government's part in supervision will be the so-called rugged individualism by state supervisory authorities, an individualism that defeats necessary interstate cooperation on national problems that confront a national business. The industry itself cannot escape blame for materially aiding this influence, because the primary responsibility for making state supervision of the insurance business a workable governmental concept rests squarely on the industry.

The state concept of supervision to the exclusion of the Federal Government also must command a much greater interest and appreciation by the people. After all,

- B.S. I9I7, University of Vermont; LL.B. 1922, Cornell University. Formerly Counsel and Deputy Superintendent of New York Insurance Department, New York Counsel for North America companics. Executive Vice President of National Association of Insurance Agents. Member of the New York bar. 1322 U. S. 533 (1944).

259 STAт. 33 (1945), as amended, 6I STAT. 448 (1947), I5 U.S.C. $\$ \$ 1011-1015$ (Supp. 1949). 
everyone concedes how intimately the insurance business is interwoven with the economic and social welfare of the people. Yet these same people, spending great sums of money in many other governmental activities, are most niggardly in many states in furnishing the necessary economic support to sustain an adequate insurance department as part of their state government. It is just as fundamental in the insurance departments of our states as it is in every department of government, namely, if you want to have good government, you, the people, must furnish the funds whereby men and women can reasonably be expected to accept and stay in the positions of government.

It must be assumed that the insurance agents feel and have felt the effects of our changing legal concepts toward the insurance business. The tremendous sales and services annually made to the people of this country is the work of the salesmen of the business, the insurance agents. These men and women bring this service into the homes of the people and the homes of our industry in every section of the whole country, and as salesmen of the service of insurance, just like salesmen of any other service or product, they must be permitted to have an abiding confidence in the service or product and everything relating to it.

So the insurance agents of the United States felt a deep concern over the effects upon insurance that would be the consequence of the decision in United States v. South-Eastern Underwriters Association. ${ }^{3}$

The thousands of agents of the United States are organized at the local, state, and national level. There are approximately 800 local agents' associations and 48 state associations, all affiliated and part of the National Association of Insurance Agents. Following the enactment of the McCarran Act, all segments of insurance company management, together with all state supervising authorities, met many times and duly considered what must be done reasonably to meet and keep faith with the provisions of the McCarran Act. In these necessary consultations the organized insurance agents of the United States contributed and participated. The agents were represented on the All-Industry Committee that undertook and successfully completed the arduous task of enacting in the several states the uniform pattern of rate regulation for the insurance business.

It is a tremendous task to bring all segments from all sections of the country together and agree upon a pattern of law. However, the pattern of law having been agreed upon, it is equally a gigantic task to accomplish the enactment of this proposed law into the various statutes of the states. The many lawyers belonging to the American Bar Association and their local bar associations which have contributed so much to the accomplishment of uniform laws, such as the Negotiable Instruments Law and Uniform Sales Law, will readily appreciate and testify to the size of the task of accomplishing uniform legislation across this country. Without the support of the organized insurance agents of this country, it is doubtful if the splendid results that the industry and supervising authorities demonstrated in ac-

\footnotetext{
${ }^{3} 322$ U. S. 533 (1944).
} 
complishing rate regulation of insurance throughout the United States could have been brought to a successful conclusion.

Before leaving this phase of agents' activities since the enactment of the McCarran Act, one should realize that relatively few states had statutory rate regulation of insurance. At the same time it was common knowledge in the insurance business that concert of action in arriving at rates in the insurance business is an economic vital necessity. Yet federal law (Sherman Antitrust Law) prohibits concert of action in price fixing - price fixing in the insurance business, of course, is the making of rates.

The necessity of accomplishing rate regulation pursuant to concert of action and under state supervision in all the states within the McCarran Act moratorium to avoid federal antitrust law entanglements, at once becomes apparent. That this was done, and within a reasonable length of time, is to the eternal credit of the insurance industry and state supervisory officials. And to this cooperative effort the insurance agents of the United States made a great contribution. This is another example of what can be done in America when business and government cooperate.

The many local organizations of insurance agents throughout the United States are organized just as any other trade or professional organization for the primary purpose of maintaining sound practices, ethics, and good public relations in their businesses or professions. As a means to this end, these local associations of agents, following the pattern of company trade associations, prescribed in their constitutions and by-laws prerequisites for membership. The legality of these rules of such local board associations became the concern of agents.

Mr. Justice Black criticized such company rules in the case of United States $v$. South-Eastern Underwriters Association: $:^{4}$

The indictment makes the following charges: The member companies of S.E.U.A. controlled go per cent of the fire insurance and "allied lines" sold by stock fire insurance companies in the six states where the conspiracies were consummated. Both conspiracies consisted of a continuing agreement and concert of action effectuated through S.E.U.A. The conspirators not only fixed premium rates and agents' commissions, but employed boycotts together with other types of coercion and intimidation to force non-member insurance companies into the conspiracies, and to compel persons who needed insurance to buy only from S.E.U.A. members on S.E.U.A. terms. Companies not members of S.E.U.A. were cut off from the opportunity to reinsure their risks, and their services and facilities were disparaged; independent sales agencies who defiantly represented nonS.E.U.A. companies were punished by a withdrawal of the right to represent the members of S.E.U.A.; and persons needing insurance who purchased from non-S.E.U.A. companics were threatened with boycotts and withdrawal of all patronage. The two conspiracies were effectively policed by inspection and rating bureaus in five of the six states, together with local boards of insurance agents in certain cities of all six states.

The kind of interference with the free play of competitive forces with which the appellees [the fire insurance companies] are charged is exactly the type of conduct which the Sherman Act has outlawed for American "trade or commerce" among the states. Appellees have not argued otherwise.

"Id. at 535-536. 
It was with a great deal of wisdom that the fire insurance companies removed these offensive rules from their organizations.

It was well known that local board organizations of agents also had rules calculated to parallel these now extinct rules of the company organizations. The fate of such rules in the agency organizations was a little different, and probably so because different legal advices were put forth.

In some places, these criticized rules, exemplified best by the so-called "in and out rule," were eliminated entirely. In others, these rules were suspended; in still others, they were allowed to remain, but in an unenforced status. In at least one instance, such rules were retained in their status quo ante the S.E.U.A. decision and enforcement thereof was attempted.

One should remember, in considering these criticized rules, that they were much more effective as a competitive force among the salesmen of the insurance business than they were effective as a competitive force among the companies. Of course, the salesmen of stock insurance would feel first the competition from mutual, independent, reciprocal, or direct writing companies. Thus one may further explain some of the reluctance to give up rules that were protective in competition with nonmembers.

Undoubtedly, the opinion of counsel for the National Association of Insurance Agents had its deterrent effect by at least slowing up in some places the relinquishment of these rules by agents' associations.

It would appear that some have unreasonably relied upon the decision in the Minneapolis Underwriters case. ${ }^{5}$

It may be well herein to indicate substantially what is meant by the so-called "in and out" rule. Such rule provides that members are prohibited from representing any company whose 2gents are not all members of the association.

In considering the legality of this rule and other criticized rules, my own concern has not been with the legality of the rules per se, though I must confess were I sitting in judgment I would not be troubled for long with such a question. Rather I have considered by what processes such rules can be effectively enforced without committing acts of boycott, coercion, unreasonable restraint, or intimidation.

It has always appeared to me that whenever and wherever such rules may exist there will always be the tendency to commit acts pursuant to such rules that may be construed as illegal under applicable Federal laws, and therefore it is my opinion that such rules should be eliminated everywhere throughout insurance organizations.

Under date of March 5, 1950, the National Association of Insurance Agents, by its Executive Committee, reached a decision which was bulletined to each of the local State Associations of Insurance Agents, informing them that the National Association of Insurance Agents would no longer aid in the continuance of the rules. This decision was reached wisely, I think, and pursuant to my own opinion given to them in the matter.

\footnotetext{
${ }^{5}$ Miller v. Minneapolis Underwriters Association, 226 Minn. 367,33 N.W. $2 d 48$ (1948).
} 
In Miller v. Minneapolis Underwriters Association, ${ }^{6}$ decided in the Supreme Court of Minnesota June Ir, I948, the plaintiff sought injunctive relief against the Minneapolis Board, alleging violation of criminal antitrust statutes.

In denying the relief to the plaintiff; the court found that the plaintiff had not shown that his property or rights of a pecuniary nature had been actually injured or forfeited. The court in commenting upon the remedy of quo warranto pointed out that the Attorney General might proceed by civil action or by quo warranto. In any event a proceeding under statute to forfeit the franchises of a corporation for violation of a criminal statute prohibiting combinations in restraint of trade is a civil action and not a criminal proceeding.

In all fairness to a reasonable interpretation of the effects of this court's decision, it must be concluded that this case is small comfort to one relying on it for authority to support rules that have been so completely dealt with in the decision of the United States Supreme Court in the South-Eastern Underwriters case.

Another concern in the activities of the agents since the enactment of the McCarran Act has been the matter of commissions. The common method of remunerating agents for their efforts in selling and servicing insurance is by the medium of the companies' permitting the agents to retain a percentage of the premium as a commission. An analysis of this subject of commissions was made by me in a paper I presented to the National Association of Insurance Agents in convention assembled at Chicago, Illinois, on September 15, 1949. In that paper, entitled "The Oldest Problem in the Insurance Business," I attempted to set forth the basic issues and principles underlying the commission problem.

It was apparent then, as it is apparent to me now, that commissions form the largest single expense item in the make-up of rate upon which the cost of insurance to the public is determined.

The statutory regulation of this item of expense-commissions-is practically nil throughout the United States. Before the decision in the S.E.U.A. case and the subsequent impact of the antitrust laws upon the insurance business, the accepted method of regulating commissions was through the medium of so-called acquisition cost conferences, which were examples of self-regulation by the insurance industry itself over this subject of commissions.

Since commissions form an integral part of the price structure of insurance, and because of the absence of state regulation over the same, these acquisition cost conferences were dissolved, obviously because the company members thereof felt themselves exposed under both state and federal antitrust laws.

It cannot be inferred that these conferences did not exercise a stabilizing influence in the business of insurance. They did, and the best example of self-regulation over this problem of commissions was illustrated by the country-wide effectiveness of the Casualty acquisition cost conference, now like all the others demised.

The National Association of Insurance Agents has a permanent committee

' Ibid. 
studying the problem of commissions, and already has completed a country-wide survey of the level of commissions paid on the various classes and kinds of insurance in the various states. The work of this committee can be integrated, and any of its findings tempered by the results of a cost survey that has also been undertaken by the National Association of Insurance Agents.

It becomes very important to any kind of salesman to know what the costs attendant upon his services are, in order to make any claim with respect to the reasonable commission or allowance for his services. The cost analysis survey undertaken by the National Association of Insurance Agents is under the guidance and assistance of a capable and competent accounting firm, and will furnish valuable and interesting cost statistics not only to agents and companies, but to supervising officials when this problem of the adequacy and reasonableness of commissions confronts them, as it inevitably will.

Just so long as commissions remain as an area within which companies may compete for business, the problem of commissions will endure.

The problem becomes acute only when in their zeal to compete for business companies offer, and agents accept, commissions higher than those heretofore paid, or higher than the prevailing level. Such a practice starts a chain of circumstances usually developing into what is commonly known as a "commission war." "Commission wars" have occurred in the insurance business, and it is unreasonable to' expect they will not occur again.

Beyond the concern of maintaining commissions at a reasonable level, whereby included therein is a profit factor to the agent over and above his out-of-pocket expenses, there is concerned in the commission problem the matter of how to compensate fairly the insurance producer or agent for his work and services in connection with policies where the premium is small.

It becomes necessary to recognize that there are thousands of policyholders in this country whose premium per policy for vitally necessary insurance coverage is nevertheless very small. Indeed it is so small that measuring the compensation to an agent by a percentage of that premium is an unworkable method of paying the agent for his services.

One must not get the idea that these small policies, small because the premium is small, are not of vital importance to the people of this country. There are literally millions of small policyholders, and if you will but consider the small premium on thousands of household furniture lines and thousands of small dwelling lines, you will recognize at once the economic problem confronting both companies and agents to devise a method of fairly compensating the agent for his service in selling and servicing these small premiums per policy insurance contracts.

Another concern of agents in connection with the subject of compensating them fairly for their services is the fact that they, the agents, along with their companies, are continually at work attempting to reduce the cost of insurance to the public. The safety and protection work already manifest practically throughout this country stems 
from the insistence of the insurance industry to improve safety and protection, and accomplishes a result that is continuously reflected in the lowering of insurance rates. Now the agent frequently finds himself in a vicious circle because the more efficiently he works in behalf of his assured in pointing out improvements in construction, in safety, and in protection, accomplishing thereby rate reductions and thus lowering the cost of insurance to the insuring public, the less compensation he receives, because commission is based on premium, and premium in turn is based on rate, and if you lower the rates you lower the premium, and you lower the commission, in dollar income, to the agents.

Nevertheless, the agents and the insurance companies of this country have steadfastly attempted to improve and advise the public to improve in matters of safety and protection, in order that rates could be reduced. The insurance business is entitled to the continuing praise of the public for this work.

However, it can be expected that over the years as we improve in the character of our construction and in safety work, a lowering of the levels of the cost of insurance will ultimately come, and it may come in many respects to an irreducible minimum, below which it is not economic for either insurance companies or agents to write insurance and to be compensated therefor so unreasonably.

At this juncture it must be repeated, because it is not said frequently enough, that the business of insurance is a business; it is not a science and has no rules that even border upon the exactness of science. At the same time there are very definite rules of economics and rules of insurance that apply to the business of insurance. Sound insurance practice commands their observance. We depart from them, and especially from the all important factor of judgment, when we attempt to become too scientific in the insurance business.

It must be admitted that the insurance agents of the United States have made a great contribution to the business of insurance since the S.E.U.A. decision and under the McCarran Act. The agents' activities in behalf of rate regulatory laws throughout the country; their activity in studying the problem of the cost to agents of transacting the insurance business; their activity in studying the very old problem of commissions; and their activity in reforming the rules that were criticized in the decision in the South-Eastern Underwriters Association case constitute their major and abundant contribution to the insurance business under the McCarran Act.

Concurrently with the efforts that the agents have made and are making in dealing with problems that have confronted and are confronting the insurance business, the agents have found time to sponsor and conduct an organized educational program in cooperation with many schools and universities, the essential effects of which will be felt in future years. Moreover, the organized insurance agents of the United States stand for, and have repeatedly demonstrated strength in the protection of, the best insurance system in the world pursuant to a free and private enterprise system. 